American University Washington College of Law

Digital Commons @ American University Washington College of Law

Articles in Law Reviews \& Other Academic Journals

Scholarship \& Research

2015

Considering Trademark and Speech Rights Through the Lens of Regulating Tobacco

Christine Haight Farley

Kavita DeVaney

Follow this and additional works at: https://digitalcommons.wcl.american.edu/facsch_lawrev

Part of the First Amendment Commons, and the Intellectual Property Law Commons 
Volume 43, Numbers 2/3 Page 289 Spring/Summer 2015

\section{CONSIDERING TRADEMARK AND SPEECH RIGHTS THROUGH THE LENS OF REGULATING TOBACCO}

\section{Christine Haight Farley and Kavita DeVaney*}

I. INTRODUCTION: TOBACCO, TRADEMARKS AND SPEECH

II. FIRST AMENDMENT AND TRADEMARK CHALLENGES TO THE REgUlATION OF THE MARKETING OF TOBACCO PRODUCTS

A. Trademarks and Plain Packaging Legislation ...................................293

B. The First Amendment Analysis of Governmental Regulation of the Marketing of Tobacco Products.

1. Central Hudson and Intermediate First Amendment Scrutiny for the Regulation of Commercial Speech......301

2. Application of Central Hudson to Plain Packaging Legislation.

C. Trademark Doctrine and Misleading Speech

III. APPLICABILITY OF FIRST AMENDMENT SCRUTINY WHEN ENJOINING NONCOMMERCIAL USES OF TRADEMARKS.

A. The Archetypical Noncommercial Use of a Tobacco Trademark ........315

B. Commentary, Parody, Satire and the Noncommercial Use of Trademarks.

C. The Applicability of Strict Scrutiny to Trademark Injunction as Content-Based Regulations on Speech

1. Trademark Injunctions as Content-Based

Regulations on Speech.

2. Consequences of Applying Strict Scrutiny to

Trademark Injunctions

D. The Necessity of Finding a Way to Subject Trademark Injunctions

to Constitutional Scrutiny .324

IV. RECONCILING SPEECH AND TRADEMARKS

V. CONCLUSION .327

* (C) 2015 Christine Haight Farley and Kavita DeVaney. Christine Haight Farley is a professor at American University Washington College of Law. Kavita DeVaney obtained her J.D. from American University Washington College of Law in 2015. 


\section{LIST OF FIGURES}

1. Figure 1. Cigarette Cartons under Australia's Plain Packaging Act............297

2. Figure 2. Marlboro \& Midwest Cigarette Packaging .......................................314

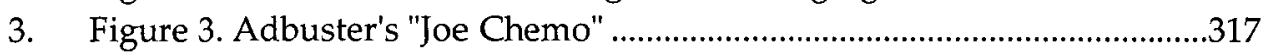




\section{INTRODUCTION: TOBACCO, TRADEMARKS AND SPEECH}

In his famous Harvard Law Review article that gave birth to trademark dilution law, Frank Schechter argued that the only rational basis for trademark protection was to protect the "true functions of the trademark," which was not just source identification, but also the ability of a mark "to stimulate further purchases by the consuming public." 1 Schechter bluntly and correctly observed that "[t]he mark actually sells the goods." 2 The "selling power" of trademarks, according to Schechter, was the result of the "psychological hold" that the mark had on the consuming public. ${ }^{3}$ Later, Justice Frankfurter similarly elucidated the psychological function of trademarks. ${ }^{4} \mathrm{He}$ explained that the owner of a mark "exploits" the human propensity to have desires induced by impregnating the atmosphere of the market with "the drawing power" of the brand. ${ }^{5} \mathrm{He}$ called this "the commercial magnetism" of trademarks. ${ }^{6}$

The commercial magnetism of trademarks is now universally accepted and must no longer be explained in law review articles or Supreme Court opinions. Marketers completely understand brand attractiveness and brand loyalty and how to fully exploit that human propensity. Intellectual property lawyers also understand brand value, which in many cases represents the most valuable asset of a company. For example, MARLBORO is currently one of the world's most valuable brands, valued at $\$ 19.7$ billion. $^{7}$ This valuation is just one way of illustrating the "psychological hold" the brand has on our collective psyche. ${ }^{8}$ But as the population of smokers is diminishing and the regulation of

1 Frank I. Schechter, The Rational Basis of Trademark Protection, 40 HARV. L. REV. 813, 818, (1927).

$2 \quad$ Id. at 819.

$3 \quad$ Id. at 831.

4 See Mishawaka Rubber \& Woolen Mfg. Co. v. S. S. Kresge Co., 316 U.S. 203, 205 (1942).

$5 \quad I d$.

6 Id.

7 The World's Most Valuable Brands: 2015 Ranking, FORBES, http://www.forbes .com/powerful-brands/list/\#tab:rank (last visited June, 2, 2015).

8 See Paul Hague, Measuring Brand Value-How Much Are Brands Worth?, B2B INTL., https://www.b2binternational.com/publications/value-of-brands/ (last visited May 16, 2015) (differentiating between goodwill and brand valuation 
tobacco is increasing, Marlboro, like other tobacco brands, is a brand whose considerable value is presently in decline. ${ }^{9}$

Examining the speech surrounding tobacco products provides a good vehicle to explore the intersection of First Amendment law and trademark law. Tobacco products speak to consumers through their advertising and packaging. The government speaks to the public about the public health dangers of tobacco through this same medium. And the public, who wants to speak about both how tobacco products are marketed as well as their harmful health effects, may speak to each other through the use of tobacco brands.

These highly-contested speech interests pit First Amendment law against government regulation, and trademark law against First Amendment law. The government would like to regulate what tobacco firms say in their advertising and on their packaging, while tobacco firms would like to control what others say about them through their trademarks. Tobacco firms argue strenuously for robust First Amendment rights when challenging government regulations, and then seek to suppress others' assertion of speech rights by using their assertion of trademark rights as a sword. When these disputes are examined side-by-side, we see that strong speech rights emerge from clear doctrine in the tobacco regulation cases, but that speech rights are vulnerable in the disorderly doctrine that has emerged in the trademark speech cases.

This article will first examine the conflict between First Amendment and trademark doctrines surrounding the regulation of the marketing of tobacco products. It will then present the presence of this same conflict in private litigation over the noncommercial use of trademarks. In conclusion, the article will posit that the two bodies of law, as they currently exist, present an untenable contradiction that needs to be resolved.

as ways of determining the premium that consumers will pay for a brand above a base line).

9 Richard Gallagher, Industry Analysis: Tobacco, VALUE LiNE, http://www.valueline.com/Stocks/Industries/Industry_Analysis_Tobacco.as px\#.VP6MboHF-Hw (last visited May 15, 2015) (stating that concerns regarding the health effect of consuming tobacco and increased government regulation have led to a steady decline in demand in the developed world). 


\section{First AMENDMENT AND TRADEMARK Challenges to the Regulation OF THE MARKETING OF TOBACCO PRODUCTS}

To examine the extent to which the government can regulate the marketing of tobacco products under the First Amendment and trademark doctrine, this section will consider hypothetical Plain Packaging legislation similar to that which has been adopted in Australia. It will discuss the level of First Amendment scrutiny that is used to determine whether a governmental regulation is constitutional before applying this scrutiny to the Plain Packaging legislation to determine whether it could withstand a constitutional challenge. This section will then consider the scrutiny applied to misleading speech under trademark doctrine and demonstrate how trademark owners obtain injunctions that escape stricter, First Amendment scrutiny, to prohibit the unauthorized commercial use of their marks.

\section{A. Trademarks and Plain Packaging Legislation}

For fifty years, governments have sought to curb smoking due to its hideous health consequences for both smokers and non-smokers. ${ }^{10}$ Tobacco is the "leading global cause of preventable death."11 In addition to resolving a major health problem, governmental action is also compelled by the severe combination of these two facts: cigarettes are addictive and the large majority of smokers start as minors. ${ }^{12}$ As the Campaign for Tobacco-Free Kids points out, "[t]obacco is the only legal product sold in the United States that, when used

10 In 1964, the Surgeon General issued a report on smoking and health saying that tobacco causes lung cancer. Advisory Comm. to the Surgeon Gen. of the Pub. Health Serv., U.S. Dep't of Health, Educ., and Welfare, Pub. No. 1103, Smoking and Health (1964). Subsequently, in 1965, the U.S. Congress passed the Federal Cigarette Labeling and Advertising Act, which required a health warning on all cigarette packs. See Federal Cigarette Labeling and Advertising Act of 1966, 15 U.S.C. $\$ \S 1331-40$ (2012).

11 World Health Organization, WHO Report on the Global tobacco EPIDEMIC, 2011: WARNING ABOUT THE DANGERS OF TOBACCO 8 (2011), available at http://whqlibdoc.who.int/publications/2011/9789240687813_eng.pdf?ua=1.

12 Child and Teen Tobacco Use, AMERICAN CANCER SOCIETY, http://www.cancer .org/acs/groups/cid/documents/webcontent/002963-pdf.pdf (last visited May 15,2015 ) ("Nearly 9 of 10 adult smokers had their first smoke by age 18."). 
according to the manufacturer's instructions, is highly addictive and kills a high percentage of its regular users." 13

In addition to heavily taxing tobacco products, Congress has attempted to curb smoking in three main areas: smoking in public places, cigarette advertising, and the appearance of cigarette packaging. ${ }^{14}$ Since 1965, health warnings have been mandated on all cigarette packaging..$^{15}$ These warnings have grown in size and severity and have become more graphic over the years. ${ }^{16}$ The most recent attempt to curb smoking also impacts the packaging and restricts how tobacco brands appear on cigarette packages. These so-called "plain packaging" measures are the latest in a long line of tobacco control regulations.

Since the implementation of the World Health Organization's (WHO) Framework Convention on Tobacco Control (FCTC) in 2005,17 a number of countries have explored the idea of adopting plain packaging for tobacco

13 See Why the FDA Should Regulate Tobacco Products, CAMPAIGN FOR TOBACCO FREE KIDS, http://www.tobaccofreekids.org/research/factsheets/pdf/0030.pdf (last visited May 15, 2015).

14 See, e.g., Public Health Cigarette Smoking Act of 1969, 15 U.S.C. § 1335 (2012) (banning the advertising of cigarettes on any medium of electronic communication); 15 U.S.C. $\$ \S$ 1331-33 (2012) (requiring all cigarette packages to carry health warnings); Cal. Lab. Code $\S 6404.5$ (West 2003) (prohibiting smoking in most California workplaces).

$15 \quad 15$ U.S.C. $\$ \S 1331-33$ (The Cigarette Labeling and Advertising Act was passed in 1965, and became effective in 1966.).

16 Niall McCarthy, The Rapid Rise of Graphic Warnings on Cigarette Packages, FORBES (Dec. 1, 2014, 8:06 AM), available at http:/www.forbes.com/ sites/niallmccarthy/2014/12/01/the-rapid-rise-of-graphic-warnings-oncigarette-packages-infographic/.

17 See World Health ORganization, WHO Framework CONVEntion on TOBACCO CONTROL (2005) [hereinafter FCTC], available at http://whqlibdoc .who.int/publications/2003/9241591013.pdf?ua $=1$. The FCTC is a WHO treaty, adopted under article 19 of the WHO Constitution at the 56th World Health Assembly on May 21, 2003. The objective of this treaty is "to protect present and future generations from the devastating health, social, environmental and economic consequences of tobacco consumption and exposure to tobacco smoke" by adopting a regulatory strategy to reduce the demand and supply of tobacco products. $I d$. at 5 . As the name suggests, the treaty is merely a framework and it is up to the signing members to ratify and implement it in good faith. 
products as a means of reducing the demand for tobacco. ${ }^{18}$ To date, Australia's Tobacco Plain Packaging Act of $2011^{19}$ is the most ambitious implementation of the FCTC framework. A number of other countries are contemplating similar regulations using the Australian legislation as a model. Ireland and the United Kingdom have recently passed legislation modeled on the Australian Act. ${ }^{20}$ Efforts to introduce plain packaging legislation are also underfoot in Canada, ${ }^{21}$ Turkey, ${ }^{22}$ Norway, ${ }^{23}$ and France. ${ }^{24}$ Broad adoption of such legislation will no

18 Reducing the Appeal of Smoking-First Experiences with Australia's Plain Packaging Law, WORLD HEALTH ORGanization (May 2013), http:/www.who.int/features/2013/australia_tobacco_packaging/en/ (stating that New Zealand, India, France, South Africa, the United Kingdom, and the European Union are considering plain packaging legislation for tobacco products).

Tobacco Plain Packaging Act 2011 (Cth) (Austl.).

Lincoln Feast, Australia at Odds with Cigarette Makers over Plain Packaging Impact, REUTERS (July 22, 2013, 7:51 AM), http://www.reuters.com/article/ 2013/07/22/us-australia-tobacco-packaging-idUSBRE96LODY20130722;

Patrick Wintour, England to Introduce Plain Cigarette Packaging Before Next Election, THE GuARDIAN (Jan. 22, 2015, 2:40 AM), http://www.theguardian .com/society/2015/jan/21/plain-cigarette-packs-general-election-tobacco; Nick Miller, As Europe Adopts Australia's Plain Packaging Reforms, Big Tobacco Fights Back, SidNey MORNING Herald (Mar. 22, 2015), http://www.smh .com.au/world/as-europe-adopts-australias-plain-packaging-reforms-bigtobacco-fights-back-20150321-1m3bwk.html.

21 Carly Weeks, Canada's Cigarette Warning Labels Could Still Go Further, Report Finds, THE GLOBE AND MAIL (Nov. 14, 2012, 3:00 AM), http://www.theglobeandmail.com/life/health-and-fitness/health/canadascigarette-warning-labels-could-still-go-further-report-finds/article 5253202.

22 Benjamin Harvey, Turkey Working on Cigarette Branding Ban Law, Milliyet Says, BlOOMBERGBusiness (Sept. 7, 2011, 1:45 AM), http://www.bloomberg .com/news/articles/2011-09-07/turkey-working-on-cigarette-branding-banlaw-milliyet-says.

Miller, supra note 20.

24 Ruth Bender, France Mulls Plain Packaging Law for Cigarettes, WaLL ST. J. (Sept. 25, 2014, 3:03 PM), http://www.wsj.com/articles/france-mulls-plainpackaging-law-for-cigarettes-1411664017; see also Solveig Godeluck et al., Tabac: le Paquet de Cigarettes "Neutre" Sans Logo Bientôt en France [Tobacco: "Neutral" Pack of Cigarettes Without Logo Soon in France], LESECHOS.FR (Sep. 23, 2014, 8:30 PM), http://www.lesechos.fr/23/09/2014/lesechos.fr/ 
doubt mean that the conflict between speech liberties and trademarks will be present for years to come.

Plain packaging laws are the next generation of efforts to curb tobacco use. In addition to assisting Australia to comply with its obligations under the FCTC, the Australian Tobacco Plain Packaging Act has three objectives: 1) to reduce the appeal of tobacco products to consumers; 2) to increase the effectiveness of health warnings on the retail packaging of tobacco products; and 3) to reduce the ability of the retail packaging of tobacco products to mislead consumers about the harmful effects of tobacco products. ${ }^{25}$

This legislative effort is called "plain packaging" because it seeks to make the health warnings more prominent by making the packaging otherwise plain. ${ }^{26}$ Brand information, which trademark lawyers know to be so commercially magnetic, is significantly downplayed on the packaging. ${ }^{27}$ For instance, the Australian Tobacco Plain Packaging Act requires tobacco products to be sold in logo-free packaging (see Figure 1). ${ }^{28}$ No non-word signs of any kind can be used other than a limited number of prescribed signs. ${ }^{29}$ According to the Act, word trademarks are permitted, but they are limited to a particular font size and type and restricted as to the space on the packaging that they can occupy. ${ }^{30}$ The color of the word trademarks is also prescribed. ${ }^{31}$ In addition, large text and

0203800487736_tabac---le-paquet-de-cigarettes--neutre--sans-logo-bientoten-france.htm\#.

25 Tobacco Plain Packaging Act 2011 (Cth) ch 1 pt 1 sec 3 (Austl.).

26 See Trefis Team, Philip Morris Braces for Ireland's Tobacco Plain Packaging Legislation, FORBES (Oct. 8, 2014, 1:48 PM), http://www.forbes.com/sites/ greatspeculations/2014/10/08/philip-morris-braces-for-irelands-tobaccoplain-packaging-legislation/ (suggesting that the legislation is intended to turn away adolescents from smoking).

27 Id. (summarizing how plain packaging laws aim is to remove "attractive packaging," presumably speaking towards tobacco products' trademarks and trade dress).

28 See Tobacco Plain Packaging Act 2011 (Cth) ch 2 pt 2 (Austl.) (outlining the requirements for retail packaging of tobacco products and for appearances of tobacco products).

29 Tobacco Plain Packaging Regulations 2011 (Cth) reg 2.3.1 (Austl.).

30 Tobacco Plain Packaging Amendment Regulation 2012 (Cth) reg 2.4.2(2) (Austl.).

31 Tobacco Plain Packaging Regulations 2011 (Cth) ch 2 pt 2 div 1 s 19 (Austl.). 
graphic warnings about smoking must cover ninety percent of the back of the packaging and seventy-five percent of the front of the packaging. ${ }^{32}$
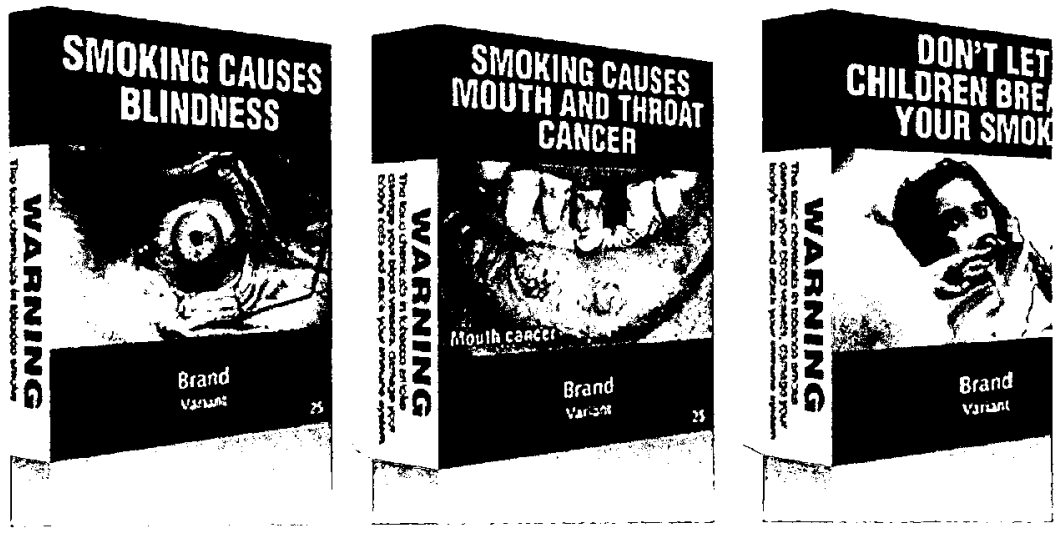

\section{Figure 1: Cigarette Cartons under Australia's Plain Packaging Act}

The legislation also provides that the opportunity to obtain registration of tobacco trademarks is not lost as a consequence of the legislation. ${ }^{33}$ Usually, an applicant for registration is required to have an intention to use a trademark. ${ }^{34}$ In the case of tobacco trademarks, the owner will not be able to use the stylized or logo mark on the product. ${ }^{35}$ And to the extent the packaging amounts to trade dress, those marks will also not be used. ${ }^{36}$ The Australian law creates an exception for tobacco trademarks and does not disqualify them from registration..$^{37}$ In addition, trademarks that are not used because of the legislation are immune from cancellation of their registration for non-use. ${ }^{38}$

Competition and Consumer (Tobacco) Information Standard 2011 (Cth) pt 9 div 4 sub-div 1 s 9.13(1), sub-div 2 s 9.19(1)(b) (Austl.).

33 Tobacco Plain Packaging Act 2011 (Cth) ch 2 pt 2 div 3 s 28(3) (Austl.).

${ }_{34}$ Id. at ch $2 \mathrm{pt} 2 \operatorname{div} 3 \mathrm{~s} 28(1)$ (a) (Austl.).

35 Id. at ch 2 pt 2 div 1 s 20 (Austl.).

36 Id.

37 Id. at ch 2 pt $2 \operatorname{div} 3$ s 28(3) (Austl.).

38 Tobacco Plain Packaging Act 2011 (Cth) ch 2 pt 2 div 3 s 28(3) (Austl.). 
This legislation has been challenged in a pending World Trade Organization (WTO) dispute that has been brought against Australia by a number of countries that are tobacco exporters: Cuba, Ukraine, the Dominican Republic, Indonesia, and Honduras (the "Complainants")..$^{39}$ Ukraine has since suspended its legal proceedings. ${ }^{40}$ The Complainants are arguing that the promulgation of the Plain Packaging Act is a violation of Australia's international trade obligations under the WTO agreements. ${ }^{41}$ The number of

39 Australia-Certain Measures Concerning Trademarks and Other Plain Packaging Requirements Applicable to Tobacco Products and Packaging, WORLD TRADE ORGANIZATION, http://www.wto.org/english/tratop_e/dispu_e/cases_e/ds434 _e.htm (last visited May 15, 2015) [hereinafter Ukraine-Australia Plain Packaging Dispute Summary] (summarizing the dispute from its commencement in May 2012 to the present day); Tania Voon \& Andrew Mitchell, Australia's Plain Tobacco Packaging Law at the WTO, THE CONVERSATION (May 15, 2013, 12:36 AM), http://theconversation.com/ australias-plain-tobacco-packaging-law-at-the-wto-14043. The Complainants allege that Australia's measures, especially when viewed in the context of Australia's comprehensive tobacco regulatory regime, appear to be inconsistent with Articles 1, 1.1, 2.1, 3.1, 15, 16, 20 and 27 of the TRIPS Agreement, Agreement on Trade-Related Aspects of Intellectual Property Rights, Apr. 15, 1994, Marrakesh Agreement Establishing the World Trade Organization, Annex 1C, 1869 U.N.T.S. 299 [hereinafter TRIPS Agreement].

40 Australia-Certain Measures Concerning Trademarks and Other Plain Packaging Requirements Applicable to Tobacco Products and Packaging: Communication from the Chairperson of the Panel, WORLd TRADE ORganization (June 2, 2015), https://docs.wto.org/dol2fe/Pages/FE_Search/FE_S_S009-DP.aspx?language= E\&CatalogueIdList $=132459,128156,127737,124459,124313,99405,82941,88093,9$ $6905,106913 \&$ CurrentCatalogueIdIndex=0\&FullTextSearch=.

41 Jaan Murphy, Australia's WTO Plain Cigarette Packaging Case: An Update, PARLIAMENT OF AUSTRALIA, http://www.aph.gov.au/About_Parliament/ Parliamentary_Departments/Parliamentary_Library/FlagPost/2014/July/WT O_plain_cigarette_packaging_case (last visited May 15, 2015) (outlining that Complainants are arguing that Australia breached the WTO General Agreement on Tariffs and Trade ("GATT") and Agreement on Technical Barriers to Trade ("TBT") agreements as the Plain Packaging Act treats imported tobacco products less favorably than domestic ones; creates unnecessary obstacles to trade and is more restrictive than is necessary to achieve a legitimate objective; and does not provide effective protection against unfair competition to nationals of other countries. Complainants also find a violation of the Agreement on Trade-Related aspects of Intellectual Property Rights ("TRIPS") and the Paris Convention for the Protection of Industrial Property as due to the Plain Packaging legislation, and state that 
WTO members who are a part of the dispute as third parties makes this the biggest and most wide-reaching dispute to date under the Agreement on TradeRelated Aspects of Intellectual Property Rights ("TRIPS"). ${ }^{42}$ This legislation is also the subject of a lawsuit in the U.K., where British American Tobacco and Philip Morris is arguing that the law violates E.U. trademark $l_{a} w_{r}^{43}$ and an investor-state arbitration proceeding, where Phillip Morris Asia is challenging the plain packaging regulations under the 1993 Agreement between the Government of Australia and the Government of Hong Kong for the Promotion and Protection of Investments. ${ }^{44}$ The tobacco company's argument purports that the plain packaging regulations are an expropriation of Phillip Morris' Australian investments and a breach of the agreement to accord fair and equitable treatment to the company's investments, as the regulations subject these investments to an unreasonable and discriminatory measure, depriving them of full protection and security. ${ }^{45}$

The main challenge to the law is that it impermissibly interferes with trademark owners' rights under the TRIPS Agreement. The Complainants contend that the TRIPS Agreement constrains the extent to which a WTO member state may regulate the trademark owner's ability to use their mark. ${ }^{46}$ The

Australia fails to protect trademarks registered internally "as is," which places unjustified barriers on the use of tobacco trade-marks and effectively denies or invalidates the registration of tobacco trademarks).

42 Guatemala, Norway, Uruguay, Brazil, Canada, the European Union, New Zealand and Nicaragua have all requested to join the consultations. In addition, Argentina, Brazil, Canada, Chile, China, Cuba, the Dominican Republic, Ecuador, Egypt, the European Union, Guatemala, Honduras, India, Indonesia, Japan, Korea, Malaysia, Malawi, Mexico, Moldova, New Zealand, Nicaragua, Nigeria, Norway, Oman, Peru, the Philippines, Singapore, Chinese Taipei, Thailand Turkey, the United States, Uruguay, Zambia and Zimbabwe have reserved their third party rights. See UkraineAustralia Plain Packaging Dispute Summary, supra note 39, at 1.

43 Tobacco Firms Challenge Plain Packaging Law, BBC News (May 22, 2015), http://www.bbc.com/news/business-32843205.

44 See Tobacco Plain Packaging-Investor-State Arbitration, AUSTRALIAN Gov'T ATTORNEY-GENERAL'S DEP'T, http://www.ag.gov.au/tobaccoplainpackaging (last visited Apr. 2, 2015). Id.

46 Request for Consultations by Cuba, Australia-Certain Measures Concerning Trademarks, Geographical Indications and Other Plain Packaging Requirements Applicable to Tobacco Products and Packaging, WT/DS458/1 (May 7, 2013); 
Complainants argue that the TRIPS Agreement, in Article 20, obligates member states to protect trademark owners' affirmative right to use their trademarks, as that article provides that use of a mark cannot be "unjustifiably encumbered" in a way that would, among other things, impair the mark's ability to distinguish a product and serve as a source identifier. ${ }^{47}$ Tobacco trademark owners claim that because Australia's legislation prohibits the use of any stylization or design and reduces the space occupied by the mark, their ability to indicate the source of origin of their product and distinguish their product from others-the two basic functions of trademarks - are impaired. ${ }^{48}$

While no similar legislation is pending in the U.S., the legislation and the challenges it faces pose an interesting question about how such legislation would interact with both U.S. trademark law and First Amendment doctrines. This article will next address the First Amendment scrutiny that is applied to the regulation of commercial speech, such as the packaging on tobacco packets, and how such legislation, if proposed, would fare under U.S. law. The article will

Request for Consultations by the Dominican Republic, Australia-Certain Measures Concerning Trademarks, Geographical Indications and Other Plain Packaging Requirements Applicable to Tobacco Products and Packaging, WT/DS441/1 (July 23, 2012); Request for Consultations by Honduras, Australia-Certain Measures Concerning Trademarks, Geographical Indications and Other Plain Packaging Requirements Applicable to Tobacco Products and Packaging, WT/DS435/1 (Apr. 10, 2012); Request for Consultations by Ukraine, Australia - Certain Measures Concerning Trademarks, Geographical Indications and Other Plain Packaging Requirements Applicable to Tobacco Products and Packaging, WT/DS434/1 (Mar. 15, 2012).

47 TRIPS Agreement, supra note 39, art. 20 ("The use of a trademark in the course of trade shall not be unjustifiably encumbered by special requirements, such as use with another trademark, use in a special form or use in a manner detrimental to its capability to distinguish the goods or services of one undertaking from those of other undertakings. This will not preclude a requirement prescribing the use of the trademark identifying the undertaking producing the goods or services along with, but without linking it to, the trademark distinguishing the specific goods or services in question of that undertaking.").

48 Emma Jones, Plain Packaging: The New IP Battleground?, PRIMARY OPINION, http://blog.primaryopinion.com/plain-packaging-the-new-ip-battleground/ (last visited May 15, 2015) (stating that the introduction of plain packaging legislation will lead to consumer confusion of both quality and origin of the goods). 
then examine the level of scrutiny applied to misleading speech under trademark law and the consequences of this lighter level of scrutiny.

\section{B. The First Amendment Analysis of Governmental Regulation of the Marketing of Tobacco Products}

This section of the article will first discuss the appropriate level of First Amendment scrutiny applicable to regulations that monitor tobacco advertising, notably the content of tobacco packaging. It will then apply this level of scrutiny to a hypothetical plain packaging act that is identical to the Australian legislation.

\section{Central Hudson and Intermediate First Amendment Scrutiny for the Regulation of Commercial Speech}

Any governmental regulation of the marketing of tobacco products along the lines of a plain packaging law would certainly face a First Amendment challenge because plain packaging legislation impinges on a trademark owner's, and presumably a business owner's, ability to speak to consumers about their product. The use of trademarks on cigarette packages would be considered speech, but it would be considered commercial speech since it proposes a commercial transaction by identifying and distinguishing the source of commercial goods. ${ }^{49}$ The Supreme Court first extended First Amendment protections to commercial speech in Virginia State Board of Pharmacy $v$. Virginia Citizens Consumer Council, Inc. because it recognized the informational value of commercial speech to the consuming public..$^{50}$ The Court recognized, however, that some regulations on commercial speech were necessary and constitutionally permissible so that the "the stream of commercial information flow cleanly as well as freely." ${ }^{51}$ Regulations that target false and misleading commercial speech; false advertising; as well as regulations on the time, manner, and place of commercial speech are not automatically prohibited by the First Amendment. ${ }^{52}$

49 See $6 \mathrm{~J}$. Thomas MCCarthy, MCCarthy ON Trademarks and UnFair COMPETITION § 31:141 (4th ed. 2015); Lisa P. Ramsey, Increasing First Amendment Scrutiny of Trademark Law, 61 SMU L. REv. 381, 395-96 (2008) (stating that the use of a trademark in commercial advertising and packaging for a specific commercial product is "pure commercial speech").

50425 U.S. 748,763 (1976).

$51 \quad$ Id. at 771-72.

$52 \quad$ Id. at 771 . 
The test for determining whether a regulation on commercial speech violates the First Amendment was provided by the Supreme Court four years after Virginia State Board of Pharmacy, in Central Hudson Gas \& Electric Corp. v. Public Service Commission. ${ }^{53}$ Central Hudson establishes an intermediate level of scrutiny for the regulation of commercial speech. ${ }^{54}$ Thus, the government may regulate truthful, non-misleading commercial speech about lawful activity if 1) the regulation serves a substantial government interest, 2) the regulation directly advances the stated interest, and 3) the regulation is no more extensive than necessary to serve that interest. ${ }^{55}$

Under this framework, false or misleading speech never receives First Amendment constitutional protections. Courts, however, only recognize commercial speech as misleading speech when it is actually or inherently misleading, not merely potentially misleading. ${ }^{56}$ Commercial speech is "actually" misleading when the record contains actual evidence of deception, ${ }^{57}$ and it is considered "inherently" misleading when the speech is disseminated in a manner that is "inherently conducive to deception and coercion." 58 This same high standard of proof is echoed in the other prongs of the Central Hudson test: the government bears the burden of demonstrating that the harms it recites are real and that the proposed regulation will in fact alleviate those harms to a material degree. ${ }^{59}$

\section{Application of Central Hudson to Plain Packaging Legislation}

An application of Central Hudson's intermediate scrutiny test to our theoretical Plain Packaging Act could result in a finding of unconstitutionality. While it is likely that the legislation should survive an examination under the

$53 \quad 447$ U.S. 557 (1980).

54 See id. at 566 .

55 Id.

56 See, e.g., Ibanez v. Fla. Dep't of Bus. \& Prof'l Regulation, 512 U.S. 136, 146 (1994).

57 Peel v. Attorney Registration \& Disciplinary Comm'n of Ill., 496 U.S. 91, 106 (1990).

58 Id. at 112 (Marshall, J., concurring).

59 Edenfield v. Fane, 507 U.S. 761, 770-71 (1993). 
first two prongs of the Central Hudson test, ${ }^{60}$ it may be more difficult to prove that it directly advances the government's stated interest and that it is no more extensive than necessary to accomplish the stated goals.

First, it is likely that courts will find that the use of tobacco trademarks in their usual form and usual manner on cigarette packages is not false or misleading. The trademark likely will have been registered by the United States Patent and Trademark Office ("USPTO"), and federal law already prohibits the false advertising of tobacco products. Moreover, the USPTO examines trademarks for the purposes of registration and will not register marks if they are either descriptive or deceptively misdescriptive under section 2 of the Lanham Act. ${ }^{61}$ Although it is possible for the USPTO to grant a registration in error, registrations for marks that are deceptive may be opposed or cancelled. ${ }^{62}$ And, although a cigarette manufacturer may use an unregistered mark on its package, this is both unlikely and risky because an infringer would certainly argue that such a mark would be invalid and unenforceable. ${ }^{63}$ In addition to trademark law,

60447 U.S. at 566. Some examples of illegal, misleading commercial speech are stating falsely that a product has received a testimonial from a respected source or stating falsely that a product has been "certified." See F.T.C. v. Colgate-Palmolive Co., 380 U.S. 374, 389 (1965). There is nothing conveyed in trademarks or trade dress of tobacco products that convey something inherently deceptive or misleading. The regulation clearly serves the governmental interest to reduce the population of smokers and increase awareness of its detrimental health effects. The government regulation, however, is most likely not reasonably tailored to this goal. See Rubin v. Coors Brewing Co., 514 U.S. 476, 490-91 (1995). In Rubin, the Court rejected legislation that prohibited beer labels from displaying their alcohol content because it was more extensive than necessary to accomplish the stated governmental interest, especially in light of the fact that there were less restrictive alternatives that accomplished this goal. See id. Here, because there are less restrictive alternatives that could accomplish the stated government interest of raising awareness of smoking's health effects, it would most likely fail the Central Hudson test.

6115 U.S.C. $\$ 1052(\mathrm{e})(2006)$.

$62 \quad 15$ U.S.C. $\$ \S 1063-4$.

63 Registration on the Principal Register provides crucial benefits, including the benefit of a statutory presumption that the mark is valid and has secondary meaning. See Andrew Stockment, Trademarks 101 Part 2: The Benefits of Federal Registration, AMERICAN BAR ASSOCIATION: YOUNG LAWYERS DIVISION, http://www.americanbar.org/groups/young_lawyers/publications/ 
the Food and Drug Administration (FDA) regulates the packaging and labeling of tobacco products and their truthfulness. ${ }^{64}$ Pursuant to the 2009 Family Smoking Prevention and Tobacco Control Act, the FDA can specifically prohibit the marketing of tobacco products with descriptors that have the potential of misleading consumers as to the health effects of consuming tobacco products (such as "light," "mild," or "low").65

Current First Amendment doctrine does not have a threshold level for what percentage of consumers must be deceived in order to find actual deception. ${ }^{66}$ But consumers are already aware of the health risks associated with smoking. Under 15 U.S.C. \$1333, cigarette manufacturers are already required to label their packages with one of a selected number of warnings addressing the harmful effects of smoking. ${ }^{67}$

Next, the government must demonstrate that the regulation serves a substantial or compelling government interest. There is likely to be little argument that reducing the appeal of tobacco products to consumers and improving the effectiveness of health warnings on tobacco products is a substantial government interest. ${ }^{68}$ The generally-recognized harmful effects of

the_101_201_practice_series/trademarks_101_part_2_the_benefits_of_federal _registration.html (last visited May 15, 2015).

64 See Regulations Restricting the Sale and Distribution of Cigarettes and Smokeless Tobacco to Protect Children and Adolescents, 61 Fed. Reg. $44,399-400$ (Aug. 28, 1996) (stating that the Rule prohibits the sale of tobacco products to minors and requires manufacturers to comply with certain conditions regarding the advertising of their products and that as the FDA has determined that cigarettes and smokeless tobacco are a combination of a drug and a device they may be regulated under the Federal Food, Drug and Cosmetic Act's drug authorities, device authorities, or both).

65 Family Smoking Prevention and Tobacco Control Act, Pub. L. No. 111-31, 123 Stat. 1776 (2009) (codified in scattered sections of 5, 15, and 21 U.S.C.).

66 See Rebecca Tushnet, Trademark Law as Commercial Speech Regulation, 58 S. C. L. Rev. 737, 748-49 (2007).

6715 U.S.C. $\S 1333(a)(1)(2012)$.

68 See, e.g., Advisory Comm. to the Surgeon Gen. of the Pub. Health Serv., U.S. Dept. of Health, Educ., and Welfare, Pub. No. 1103, Smoking and Health, 33 (1964) ("Cigarette smoking is a health hazard of sufficient importance in the United States to warrant appropriate remedial action."); Regulations Restricting the Sale and Distribution of Cigarettes and Smokeless Tobacco to Protect Children and Adolescents, 61 Fed. Reg. 44,399 
smoking ${ }^{69}$ should satisfy the government's burden of demonstrating that the harms it recites are real. This argument is similar to Australia's argument in the WTO dispute. ${ }^{70}$ Cigarette advertising and packaging is a powerful way for tobacco companies to market their products to young audiences. Research on smoking suggests that if people do not start smoking at a young age, they will forgo smoking their entire lives. ${ }^{71}$ Accordingly, plain packaging is a powerful, preemptive deterrent because it interferes with brand image. Plain packaging will cause tobacco products to lose their cachet, and appealing packages will become dull and uninteresting. ${ }^{72}$ In this respect, the branding on packages is analogous to tobacco advertising and as such ought to be regulated in a similar manner.

The government may also be able to demonstrate that the Plain Packaging Act directly advances its stated interests of reducing the appeal of tobacco products, improving the effectiveness of health warnings on tobacco products, and reducing the ability of cigarette manufacturers to mislead the public about the harmful effects of tobacco products. At least one tobacco company has acknowledged that it uses its packaging to promote the products of one cigarette manufacturer over another and to differentiate its products from that of competitors. ${ }^{73}$ Furthermore, a number of studies have demonstrated that

(Aug. 28, 1996) (affirming that the purpose of these regulations was to substantially reduce the number of children and adolescents who begin using tobacco, and therefore, reduce tobacco-related illness).

69 See, e.g., U.S. Dep't of Health and Human Servs., Effects of Smoking on Your Health, BETOBACCOFREE.GOV, http://betobaccofree.hhs.gov/health-effects/ smoking-health/ (last visited May 15, 2015).

70 See Murphy, supra note 41 (stating that one of Australia's counter arguments to the Complainants in the WTO case is that the plain packaging legislation is a necessary measure designed to pursue the legitimate objective of the protection of human health).

71 Child and Teen Tobacco Use, supra note 12.

72 Michelle Innis, Australia's Graphic Cigarette Pack Warnings Appear to Work, N.Y. TIMES (June 11, 2014), http://www.nytimes.com/2014/06/12/business/ international/australias-graphic-cigarette-pack-warnings-appear-towork.html (quoting the New Zealand associate health minister regarding how plain packaging "takes away the last means of promoting tobacco as a desirable product").

73 Mark Davison \& Patrick Emerton, Rights Privileges, Legitimate Interests, and Justifiability: Article 20 of TRIPS and Plain Packaging of Tobacco, 29 AM. U. INT'L. L. REV. 505, 567 (2014). 
the plain packaging of cigarettes provokes a decrease in the appeal of the product, as plain packages were found to be associated with lower quality cigarettes, which project a less desirable smoker identity and further expose the harmful effects of smoking. ${ }^{74} \mathrm{~A}$ majority of the studies researching the effectiveness of plain packaging in highlighting the warnings on cigarette packages found that plain packaging increased the salience of warnings on cigarette packages for two reasons: first, there was less clutter on the packages to detract from the warnings; and second, the dullness and seriousness of the packages themselves increased the gravity of the warnings and consequences of smoking. ${ }^{75}$

All of these findings are generally in line with the FCTC proposition that plain packaging reduces the appeal of cigarette products, increases the effectiveness of health warnings on packaging, and reduces consumer confusion about the comparative level of harm provoked by one cigarette brand over another. ${ }^{76}$ To date, over 168 nations have signed the FCTC, signaling a widespread, international recognition of the FCTC propositions. ${ }^{77}$

Despite all the evidence pointing toward the ability of plain packaging to achieve its stated goals, whether or not plain packaging can actually reduce the number of smokers is still contested. ${ }^{78}$ Australia's experience with plain packaging legislation, after a period of time, may provide the evidence that could

74 Crawford Moodie et al., Plain Tobacco Packaging: A Systematic Review, UNIV. STIRLING 1, 84-85 (2012), http://phrc.lshtm.ac.uk/papers/PHRC_006_Final_ Report.pdf (providing a comprehensive summary of the major studies addressing the effects of plain packaging of cigarettes).

75 Id. at $85-86$.

76 See id. at 84 .

77 Parties to the WHO Framework Convention on Tobacco Control, WORLD HEALTH ORGANIZATION FRAMEWORK CONVENTION ON TOBACCO CONTROL, http://www.who.int/fctc/signatories_parties/en/ index.html (last updated Feb. 12, 2015) (stating that there are 180 parties to the WHO FCTC and 168 signatories). The U.S. has not yet ratified the convention.

78 See, e.g., No Evidence That Plain Cigarette Packs Work, Says Industry Funded Study, National Health Service (NHS), http://www.nhs.uk/news/2014/ 03March/Pages/Plain-fags-packs-dont-work-says-industry-fundedstudy.aspx (last visited May 15, 2015) (providing a study that showed that the long-term trend in Australia of declining smoke rates did not dramatically change the year after the plain packaging legislation was introduced). 
lead to a consensus about the positive effects of the legislation. The decreased appeal of tobacco products resulting from plain packaging may have the greatest impact on adolescents who have yet to acquire brand loyalty to a particular cigarette or who smoke less regularly than their peers. ${ }^{79}$ Due to this lingering doubt that plain packaging legislation is actually effective in achieving its objective of reducing the appeal and thus the number of smokers, a court may decide that the legislation does not satisfy the third prong of the Central Hudson test. 80

The last prong of the Central Hudson test requires that the plain packaging regulation be no more extensive than necessary to serve the government's stated interest in passing the legislation. ${ }^{81}$ It is this prong of the Central Hudson test that will pose the greatest challenge to the hypothetical Plain Packaging Act. The Court has already expressed a preference for the use of disclaimers over the suppression of speech, especially where that suppression represents a complete prohibition. ${ }^{82}$ Therefore, it is possible that the Court would countenance the expansion of 15 U.S.C. $\$ 1333$ rather than a new law that would completely prohibit certain speech. For example, the requirement that the warnings occupy ninety percent of the back of the packaging and seventy-five percent of the front of the package could be incorporated into the current statute which already mandates that a warning label be placed on cigarette packages with a certain color scheme and font size. ${ }^{83}$ The ban on the use of non-word signs is not a complete ban on speech, but it is a significant incursion on the speech. By

79 See Suzi Gage, Will Plain Packaging of Cigarettes Work? A Look at the Current Evidence, THE GUARDIAN, http://www.theguardian.com/science/sifting-theevidence/2013/mar/07/plain-packaging-cigarettes-current-evidence (last updated May 21, 2014, 12:30 AM).

80 See 447 U.S. 557, 566 (1980) (stating that to determine whether a governmental restriction on speech satisfies the First Amendment, it must directly advance the governmental interest asserted). Id.

82 See e.g., Zauderer v. Office of Disciplinary Counsel of Supreme Court of Ohio, 471 U.S. 626, 651 (1985) (stating that because disclosure requirements impinge less on a speaker's interests than a complete prohibition on speech, warnings or disclosures can be required in order to reduce the possibility of consumer confusion or deception).

8315 U.S.C. $\S 1333(2)$ (2012) (mandating that the text of the warning be in seventeen point type, and be black or white on a contrasting white or black background). 
banning the use of non-word marks on cigarette packages and strictly regulating the font type and size of word marks, the Plain Packaging Act strives to achieve uniformity across all cigarette packaging. ${ }^{84}$

The broad approach of the Plain Packaging Act could be perceived by the Court as being more extensive than is necessary to achieve the government's interest behind plain packaging. Whether or not this regulation is more extensive than is necessary may rest on the answer to the question of whether such uniformity in cigarette packaging is necessary to produce the desired health benefits. The uniformity in packaging resulting from the legislation would ensure both that the health warnings dominate the visual landscape and that the brand image is completely diminished..$^{85}$ The plain package would therefore also have a post-sale impact as third parties would not be enticed by the package. ${ }^{86}$

The recent case of R.J. Reynolds Tobacco Co. v. FDA ${ }^{87}$ illustrates the contentious ground that currently exists when courts are faced with government regulations of tobacco products. In that case, tobacco companies brought a First Amendment challenge to the FDA's promulgation of a rule requiring tobacco companies to market cigarettes in packaging containing a graphic warning label. ${ }^{88}$ The court found that the governmental interest as stated in the FDA rule

See Victoria Parr et al., GfK Bluemoon, Market Research to Determane Effective Plain PaCKaging of TOBacco Products 21 (2011), available at http://web.ff.cuni.cz/novyweb/utrl/files/MarketResearch-PlainPackagingof TobaccoProducts.pdf (stating that the market research prior to the implementation of the plain packaging legislation aimed at identifying one plain packaging design (color, font type, font size) that would minimize appeal and attractiveness while maximizing perceived harm).

8515 U.S.C. $§ 1333(\mathrm{~b})$ (2012) (mandating that between $50 \%$ and $70 \%$ of packaging contain warning labels).

86 See Matt Siegel, Law Spoils Tobacco's Taste, Australians Say, N.Y. TIMES (July 10, 2013), available at http:/www.nytimes.com/2013/07/11/business/global/ law-spoils-tobaccos-taste-australians-say.html (describing how Australian smokers were complaining after the enactment of the Plain Packaging legislation, and arguably, according to the Prime Minister, it was the "ugly packaging" that was making the smokers take the psychological leap to sensing a "disgusting taste").

$88 \quad$ Id. at 1208. 
was the reduction of smoking rates, particularly in children and adolescents. ${ }^{89}$ The court, however, found that the government failed to meet its burden as the FDA offered no evidence showing that graphic warnings on cigarette packages "directly caused a material decrease in smoking rates" in any other country that had adopted similar measures. 90

The dissenting opinion argued that the majority applied the wrong standard of scrutiny. ${ }^{91}$ It focused on the tobacco companies' long history of misleading consumers $^{22}$ and the governmental interest in effectively communicating the negative health consequences of smoking to the public. ${ }^{93}$ The dissent concluded that the government needed to only show that the graphic warnings were reasonably related to its stated and substantial interest in effectively conveying information to consumers and that the targeted commercial speech presented a tendency to mislead consumers under the Zauderer standard. ${ }^{94}$ The dissent found there was sufficient evidence demonstrating that current warnings on cigarettes were ineffective. ${ }^{95}$ It also found that the textual information contained in the graphic warnings was factual and that the entirety of the warnings was reasonably related to the stated government interest of effectively communicating the risks of smoking to consumers. ${ }^{96}$ The dissent further opined that the majority misapplied the Central Hudson level of scrutiny..$^{97}$ This misapplication occurred through the majority's failure to examine both of the government's stated interests: (1) ensuring the accuracy of commercial information in the marketplace; and (2) the reduction in smoking rates..$^{98}$

89

90

91

92

93

94

Id. at $1222-23$.

Id. at 1219 .

Id. at 1222 (Rogers, J., dissenting).

See R.J. Reynolds Tobacco Co., 696 F.3d at 1224-25.

Id. at 1223 .

Id. at 1222-23 (citing Zauderer v. Office of Disciplinary Counsel of the Supreme Court of Ohio, 471 U.S. 626, 650-51 (1985)).

R.J. Reynolds Tobacco Co., 696 F.3d at 1224 (citing INSTITUTE OF Medicine, ENDING THE TOBaCCO PROBLEM: A BLUEPRINT FOR THE NATION 5, 291 (2007)).

R.J. Reynolds Tobacco Co., 696 F.3d at 1233.

Id. at 1235 .

Id. (citing Rubin v. Coors Brewing Co., 514 U.S. 476, 485 (1995); Edenfield v. Fane, 507 U.S. 761, 769 (1993)). 
Although numerous questions remain and the evidence of the effects of plain packaging laws on curbing tobacco use is not yet known, it is possible that a U.S. Plain Packaging Act could survive. First Amendment scrutiny under Central Hudson. Such legislation, however, may be found to curtail the commercial speech rights of tobacco companies and be struck down as not directly advancing the stated interest of the act or as being more burdensome than necessary to achieve the stated objective of the act.

The First Amendment poses enormous obstacles when the government attempts to regulate the advertising of tobacco products.99 Interestingly, tobacco trademark owners escape similar barriers when seeking to exclude the speech of others who use their marks under doctrines from trademark law. 100 The next section of this article will examine this dichotomy.

\section{Trademark Doctrine and Misleading Speech}

The stated intent of the Lanham Act is "to regulate commerce within the control of Congress by making actionable the deceptive and misleading use of marks in such commerce."101 The standard for what is "deceptive and misleading," however, differs significantly from the standard applied under the Central Hudson test. This difference opens the door for trademark owners to bypass strict First Amendment scrutiny when seeking to enjoin others from making commercial use of their marks.

The goal of the Lanham Act is to prevent consumer confusion as to the source of goods and services and misrepresentation as to the nature, characteristics, or qualities of commercial goods. ${ }^{102}$ Under trademark law, the standard for infringement of a trademark owner's mark is a likelihood of consumer confusion; proof of actual deception by consumers is not required. ${ }^{103}$ The Lanham Act also contains provisions addressing false advertising that make actionable the marketing of any commercial good or service that is likely to cause confusion as to the nature of characteristics of the good or a competitor's

99 See R.J. Reynolds Tobacco Co., 696 F.3d at 1205.

100 See generally J. THOMAS MCCARTHY, supra note 49 \$ 23:18.

$101 \quad 15$ U.S.C. $\S 1127$ (2012).

102 See 15 U.S.C. $\$ 1125$ (a)(1) (2012).

103 J. THOMAS MCCARTHY, supra note 49, § 23:18 (stating that the standard of finding infringement in trademark law is likelihood of confusion, even without evidence of actual past confusion). 
goods. ${ }^{104}$ This doctrine is in complete contrast to First Amendment doctrine described above, which requires that there be proof of actual or inherent deception in order for speech to not receive First Amendment constitutional protections. ${ }^{105}$ Therefore a trademark owner has broad rights under the Lanham Act to curtail the speech of others who infringe the trademark.

The application of these different standards of confusion to determine whether use of a mark should be allowed is illustrated by considering Piazza's Seafood World, LLC v. Odom. ${ }^{106}$ In Piazza's Seafood World, the plaintiffs sold Chinese-farmed catfish under the trade names "Cajun Boy" and "Cajun Delight" in violation of the Louisiana Cajun Statute, which required that any food product that was marketed under a trade name containing the word "Cajun" be produced, processed, or manufactured in Louisiana. ${ }^{107}$ The Fifth Circuit found that the use of "Cajun" in this case was only potentially misleading because the food product's packaging also indicated the actual country of origin. ${ }^{108}$ The court held that while the government had a substantial interest in preventing consumer deception, the statute was overbroad because there was no showing of actual deception. ${ }^{109}$ If, however, this same case had been brought under the Lanham Act, the USPTO could have refused registration of the trade names "Cajun Boy" and "Cajun Delight" on the basis of potential consumer confusion."10 The differing outcome under these two scenarios is the result of the different standards for false and misleading speech that have emerged under First

10415 U.S.C. $\$ 1125(a)(1) ; 44$ AM. JUR. Proof of Facts 3d 1, $\$ 6$ (1997) (stating that under the Lanham Act one category of false advertising is the making of "false representations concerning one's own goods and services, while the second category concerns false representations of the goods or services of another").

105 Similarly, the USPTO can refuse registration of a mark if it finds that registration has the potential of confusing consumers. 15 U.S.C. $\S 1052$ (d) (2012).

106448 F.3d 744 (5th Cir. 2006).

107 Id. at $746-47$.

$108 \quad$ Id. at 753 .

109 See id.

110 Tushnet, supra note 66, at 751 (asserting that if the plaintiff had sought to register the mark "Cajun Boy" with the PTO it could have been denied registration because the examiner does not have to show actual deception to deny registration of a mark). 
Amendment and trademark doctrines. ${ }^{111}$ The practical effect of this is that few defendants in trademark infringement cases raise First Amendment defenses, and courts do not generally apply a constitutional analysis to trademark laws or injunctions upon a finding of infringement. ${ }^{112}$

When First Amendment doctrine is juxtaposed with trademark law in the context of plain packaging, divergent standards are revealed. Were Australia's Plain Packaging Act passed in the United States, the tobacco industry would certainly raise a First Amendment challenge. ${ }^{113}$ This challenge would claim speech rights in the manner in which tobacco trademarks are displayed. Under plain packaging legislation, tobacco companies are free to use their mark on tobacco packages, but they are prohibited from using any trade dress or design features. ${ }^{114}$ Thus, the speech claim will be for these design elements. ${ }^{115}$

111 See Ramsey, supra note 49, at 415 (stating that upon finding trademark infringement, most judges dismiss First Amendment concerns by making the cursory analysis that commercial speech may be regulated when it is false or misleading without considering whether the infringing use really meets the First Amendment's high threshold of misleading speech). Compare R.A.V. v. City of St. Paul, Minn., 505 U.S. 377, 380, 391 (1992) (invalidating ordinance criminalizing the use of a symbol that "arouses anger, alarm or resentment in others"), Boos v. Barry, 485 U.S. 312, 318-19, 334 (1988) (striking down a statute that prohibited speech critical of foreign governments in the proximity of their embassies, while allowing favorable speech), Cornelius v. NAACP Legal Def. and Educ. Fund, 473 U.S. 788, 812 (1985) ("[T]he purported concern to avoid controversy excited by particular groups may conceal a bias against the viewpoint advanced by the excluded speakers."), with 15 U.S.C. § 1052(a) (Lanham Act (L.A.) § 2(a)) (prohibiting the registration of any trademark interpreted by the P.T.O. to be immoral, scandalous, or disparaging, a determination which is based on whether the public would consider the particular mark offensive).

Ramsey, supra note 49 , at 385.

113 See, e.g., R.J. Reynolds Tobacco Co. v. FDA, 696 F.3d 1205 (D.C. Cir. 2012) (where tobacco companies brought a First Amendment challenge to the FDA requiring tobacco companies to market cigarettes in packets containing an illustrated warning label).

Tobacco Plain Packaging Act 2011 (Cth) ch 2 pt 2 (Austl) (limiting the retail packaging of tobacco products such that any distinctive characteristics of the product or its packaging would no longer be apparent). 
Interestingly, tobacco trademark owners have sought to enjoin precisely this speech by others. When competitors use similar fonts or design elements on their packaging, tobacco trademark owners have successfully used trademark law as a means to restrain this speech. For instance, Philip Morris obtained a preliminary injunction against a competitor that used a similar font, color scheme, overall composition and crest to the well-known Marlboro cigarette package (see Figure 2). ${ }^{116}$ Even though the competitor's product was clearly marked with its "MidWest" brand and there were notable differences in the packaging design, font, and crest, the Eastern District of Virginia found that there was a likelihood of consumer confusion and enjoined the competitor's use of these design features. ${ }^{117}$ Although the court found that consumers would confuse the two packages, this is clearly a different standard than the actual deception required by First Amendment law to prohibit commercial speech. ${ }^{118}$ This discord between the two claims made by tobacco companies exposes the divergence between trademark and First Amendment doctrines.

Philip Morris, Inc. v. MidWest Tobacco, Inc., 9 U.S.P.Q.2D (BNA) 1210 (E.D. Va. 1988).

117 Id.; accord R.J. Reynolds Tobacco v. Va. Int'l Export, 220 U.S.P.Q. (BNA) 712 (E.D. Va. 1982) (enjoining the use of design elements similar to the packaging of Winston cigarettes even where a different trademark is employed); Philip Morris, Inc. v. Rothmans of Pall Mall Ltd., 180 U.S.P.Q. (BNA) 592 (T.T.A.B. 1973) (concluding that cigarette packages marked with the Rothman trademark were nonetheless likely to cause confusion with Virginia Slims cigarettes because of packaging that each employed colored vertical stripes).

See Phillip Morris Inc., 9 U.S.P.Q.2D 1210 (stating that actual confusion is not required to find a violation of the Trademark Act and that a likelihood of confusion was established, leading to a strong likelihood that plaintiffs would prevail on the merits). 

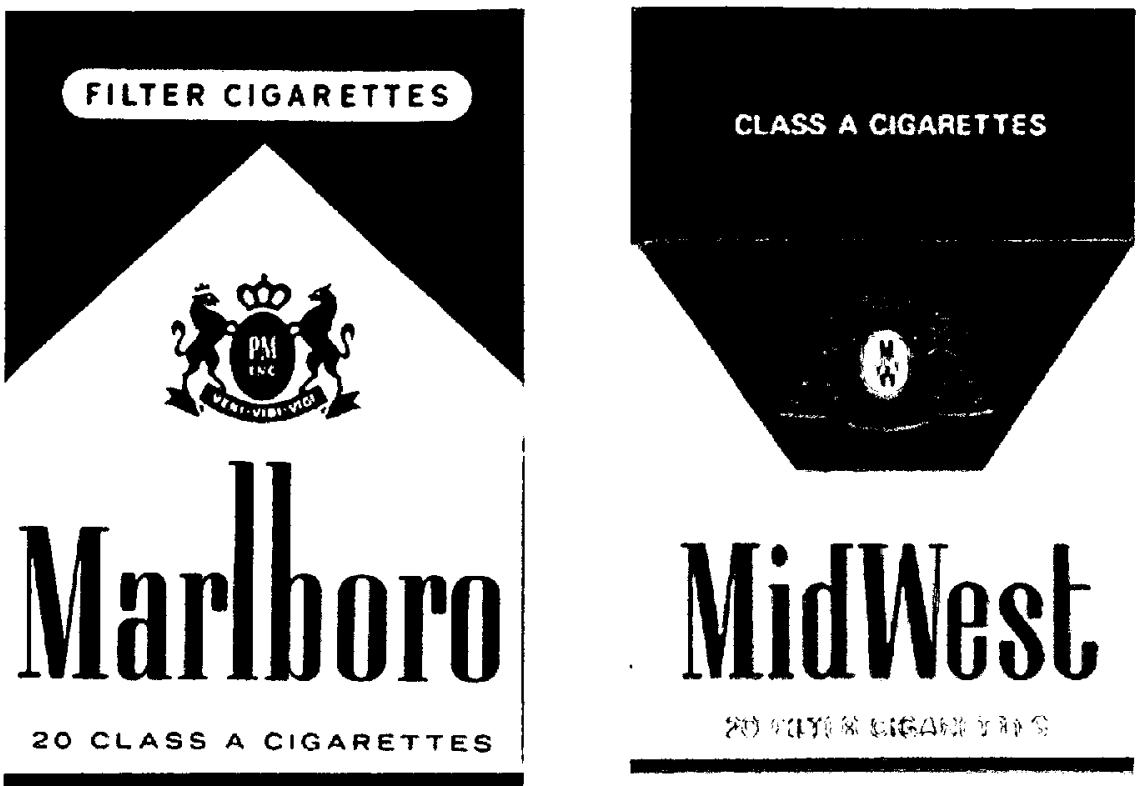

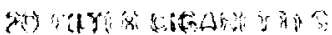

Figure 2: Marlboro \& Midwest Cigarette Packaging

\section{APPLICABILITY OF FIRST AMENDMENT SCRUTINY WHEN ENJOINING} NONCOMMERCIAL USES OF TRADEMARKS

The preceding section of this article discussed the conflict between First Amendment and trademark law within the scope of commercial uses of tobacco trademarks. This section will demonstrate that this same conflict exists when trademarks are used for noncommercial purposes. This inconsistency has yet to appear manifestly in case law, because courts rarely apply the First Amendment strict scrutiny standard to injunctions against the noncommercial use of trademarks. ${ }^{119}$ Within the scope of this article, the two ways in which a speech regulation could be subjected to intermediate, and not strict scrutiny is if 1) the

119 See Ramsey, supra note 49, at 385 (stating that most courts will not apply a constitutional analysis to trademark injunctions because they consider that the requirement of state action is not satisfied; that certain uses of a trademark are not speech as defined under the First Amendment; that there is an assumption that infringing commercial use of a mark is misleading commercial speech; or that trademark laws are content-neutral speech regulations, not subject to strict scrutiny). 
use of the trademark is commercial or 2) the regulation is content-neutral. ${ }^{20}$ In the instance of the noncommercial use of tobacco trademarks, neither of these criteria for an intermediate level of scrutiny is satisfied.

To explore why, contrary to current practice, injunctions against the noncommercial use of tobacco trademarks should be subjected to First Amendment strict scrutiny, this section will present a hypothetical private litigation claim between a tobacco company and an anti-smoking advertising campaign. This hypothetical will demonstrate that most activist use of trademarks satisfies the noncommerciality requirement and that the injunctions issued against such activist use of marks are content-based and therefore should be subject to the strict scrutiny First Amendment test. The last part of this section will focus on the reasons why trademark injunctions are not currently subjected to strict scrutiny.

\section{A. The Archetypical Noncommercial Use of a Tobacco Trademark}

"Joe Camel" was a trademark used by R.J. Reynolds to promote Camel brand cigarettes until 1997..$^{121}$ Adbusters Media Foundation is a global network of artists, writers, students, educators, entrepreneurs, and activists who offer critical commentary on commercial culture through the ads and articles in their magazine and website. ${ }^{122}$ Its magazine, Adbusters, regularly features advertisement parodies, known as "spoof ads" or "subvertisements" which use trademarks and corporate logos to create awareness about social and political

120 It should also be noted that some arguments exist that Section 2(a) of the Lanham Act itself should be subjected to strict scrutiny as its prohibition of the registration of any mark interpreted by the USPTO to be immoral, scandalous or disparaging to any persons, institutions, beliefs or national symbols mandates view-point discrimination of expressive private speech. See generally Brief for American Civil Liberties Union \& American Civil Liberties Union of Virginia as Amici Curiae Supporting Petitioners, ProFootball, Inc. v. Amanda Blackhorse, No. 1:14-cv-01043-GBL-IDD (E.D. Va.) (filed Mar. 5, 2015), available at https://www.aclu.org/free-speech/profootball-inc-v-blackhorse-aclu-amicus-brief.

121 R. J. Reynolds voluntarily abandoned this mark as part of an out-of courtsettlement in a case that charged the company with targeting minors with the logo. Myron Levin, RJR Agrees to Pull Joe Camel From Ads, LA TIMES (July 11, 1997), available at http://articles.latimes.com/1997/jul/11/business/fi-11650.

122 Adbusters: About, ADBUSTERS MEDIA FOUNDATION, http://www.adbusters.org/ about/adbusters/ (last visited May 15, 2015). 
issues. ${ }^{123}$ In this vein, Adbusters created the character of "Joe Chemo" to parody the "Joe Camel" trademark and to raise awareness of the health issues surrounding smoking. ${ }^{124}$ Joe Chemo closely resembles Joe Camel, except he is dying of cancer. ${ }^{125}$ In one spoof ad, Joe Chemo is depicted lying in a hospital bed, ${ }^{126}$ in another, walking the corridor of a hospital with an IV pole, ${ }^{127}$ and then in a third, lying in a casket (see Figure 3). ${ }^{128}$ The Adbusters images also make use of the same typeface found on Camel cigarette packages. ${ }^{129}$ According to the campaign, the purpose of the adaptation is to present a "more honest" image of smoking than that evoked by the R.J. Reynolds' Joe Camel character. ${ }^{130}$

Now imagine that Joe Chemo is used as a mascot and as a designation of source for an anti-smoking campaign and that this organization sells Joe Chemo $\mathrm{t}$-shirts to defray the cost of the campaign. ${ }^{31}$ Further imagine that R.J. Reynolds sued the organization for infringing and diluting their trademark.132 R.J. Reynolds could bring both a dilution by blurring and a dilution by tarnishment

123 See id.; see also David Moore, Adbusters, Poking Back at Advertisers, MEDIA LIFE MAGAZINE (July 9, 2002), http://www.medialifemagazine.com:8080/ news2002/jul02/jul08/2_tues/news4tuesday.html (describing Adbusters' activity as parodies of well-known ad campaigns that works by "jamming" the existing consumer culture, allowing it to be reclaimed by civil society).

See Spoof Ads: Tobacco, AdBusters MEdia Foundation, http://adbusters .org/spoofads/tobacco/ (last visited May 15, 2015); More About Joe, JOE CHEMO, http://www.joechemo.org/about.htm (last visited May 15, 2015).

More about Joe, supra note 124.

Joe Chemo - Bed (1996), Adbusters Media Foundation, https://www.ad busters.org/content/joe-chemo-bed (last visited May 25, 2015).

Joe Chemo - Hallway (1996), AdBusters Media Foundation, https://www.ad busters.org/content/joe-chemo-hallway (last visited May 25, 2015).

Joe Chemo - Funeral (1996), AdBUSTERS MEdia FOUNDATION, https:/www.ad busters.org/content/joe-chemo-funeral (last visited May 25, 2015).

Id.

More about Joe, supra note 124.

Trademark Dilution Revision Act of 2005: Hearing on H.R. 683 Before the Subcomm. on Courts, the Internet, \& Intellectual Prop. of the H. Comm. on the Judiciary, 109th Cong. 30 (2005) [hereinafter Trademark Dilution Revision Act] (statement of Marvin J. Johnson, Legislative Counsel, American Civil Liberties Union) (providing hypothetical dispute).

Id. 
claim against the organization, ${ }^{133}$ since the suave and debonair figure promoting Camel cigarettes is now associated with the sickly, in-need-of-treatment camel. Since the fair use defense does not apply in cases where the defendant is using the mark as a designation of source, ${ }^{134}$ the organization would be left to argue the substantive claim of dilution. R.J. Reynolds would not have to prove that the organization actually diluted the trademark, only that there is a likelihood of dilution. ${ }^{135}$ Since the organization intended to create an association with the famous Joe Camel mark, the factor of "[w]hether the user of the mark or trade name intended to create an association with the famous mark" 136 will certainly count against it.
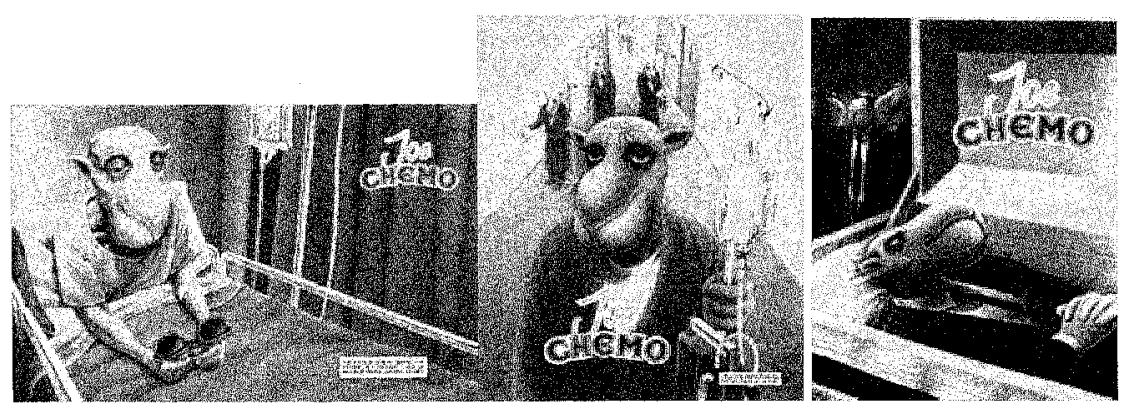

Figure 3: Adbusters' "Joe Chemo"

\section{B. Commentary, Parody, Satire and the Noncommercial Use of Trademarks}

Trademark litigation between private parties is not only limited to instances where a commercial competitor makes an unauthorized use of a trademark owner's mark to promote his own product or service. ${ }^{137}$ Increasingly, groups with political, social, and environmental agendas may make

133 Id

134 See 15 U.S.C. \$1125(c)(3)(A) (2012).

135 Trademark Dilution Revision Act, supra note 131.

136 See 15 U.S.C. $\$ 1125(\mathrm{c})(2)(\mathrm{B})$.

137 See, e.g., Deere \& Co v. MTD Prods., Inc., 41 F.3d 39, 41 (2d Cir. 1994) (observing that defendant company used the plaintiff's deer logo mark in a television advertisement for the purpose of parodying the trademark owner). 
unauthorized uses of marks to further the goals of their organizations. ${ }^{138}$ Where the unauthorized use of another's mark has a communicative value such as to express commentary, parody, or satire, the use of the trademark does not rise to the level of "misleading" commercial speech regardless of whether it causes an association with the trademark owner or not. ${ }^{139}$

Even though some of these groups produce merchandise carrying their parodies, the mere placement of these statements on goods for sale is not per se commercial speech and therefore the unauthorized uses of marks in this context should be analyzed under strict scrutiny analysis. ${ }^{140}$ For example, in Riley $v$. National Federation of the Blind, the Supreme Court held that where the noncommercial nature of the speech predominates, or the commercial and noncommercial components are inextricably intertwined, restrictions on that expression should be evaluated under the test for fully protected expression. ${ }^{141}$

See, e.g., Radiance Found. Inc. v. Nat'l Assoc. for the Advancement of Colored People (NAACP), No. 14-1568, 2015 WL 2372675, at *1 (4th Cir. May 19,2015 ) (where the founder of the defendant organization drafted an article using the plaintiff's trademarked name to criticize their perceived defiance of Christian values, perpetration of racist stereotypes and ties to Planned Parenthood); Ramsey, supra note 49, at 397 (giving the example of politicians who make unauthorized use of trademarked terms to convey political ideas).

139 See, e.g., Radiance Found. Inc., 2015 WL 2372675, at *6 (stating that in conducting the likelihood of confusion inquiry, the infringer's intent must be taken into account, the other factors of the confusion analysis must be evaluated in light of that intent and purpose, and that an intent to parody is not an intent to confuse the public) (citing Louis Vuitton Malletier S.A. v. Haute Diggity Dog, LLC, 507 F.3d 252, 261 (4th Cir. 2007)); Ramsey, supra note 49 , at 418-19.

140 See Ramsey, supra note 49, at 418-19 ("In such cases, further constitutional scrutiny of the trademark restriction is required because the speech also conveys useful information or ideas to consumers.").

141487 U.S. 781, 796 (1988) ("But even assuming, without deciding, that such speech in the abstract is indeed merely 'commercial,' we do not believe that the speech retains its commercial character when it is inextricably intertwined with otherwise fully protected speech."); see also Louis Vuitton Malletier S.A., 507 F.3d at 261 (finding even when the primary purpose of the satirist is commercial, an exception for parody is still operable when the court held that the trademark of "Chewy Vuiton" toy dogs was "a comment on the rich and famous, on the LOUIS VUITTON name and related marks, and on conspicuous consumption in general."). 
Furthermore, in determining whether speech is commercial, courts consider several factors: 1) whether the speech is an advertisement; 2) whether speech refers to specific products or services; 3 ) whether the speaker has an economic motivation and 4) whether the listener would perceive the speech as proposing a transaction. ${ }^{142}$ The key to making this determination is whether a reasonable listener could think that a commercial transaction is being proposed. ${ }^{143}$ Therefore, as long as it could reasonably be interpreted that the social commentators' main purpose was to relay their social message and not enter into commercial transactions, despite the appearance of merchandise bearing their logos, their speech under the Fourth Circuit factors would not be deemed commercial.

Trademark owners nevertheless sometimes seek to apply the Lanham Act even where the unauthorized use of the mark is an arguably noncommercial use. ${ }^{144}$ In these cases, the classification of the use as commercial or noncommercial could be determinative, as federal trademark dilution law only applies to commercial speech. ${ }^{145}$ If we were to apply this distinction between commercial or noncommercial use of a mark to the Adbusters' Joe Chemo campaign there is a strong argument that the use of the Joe Camel logo would be found to be noncommercial. First, the stated goal of Adbusters' subvertisments is to create awareness about social and political issues. Specifically, the adaptation of the Joe Camel logo is to present a "more honest" image of smoking than that provided by the tobacco company. ${ }^{146}$ Secondly, the sale of $t$-shirts is undertaken

142 Radiance Found. Inc., 2015 WL 2372675, at ${ }^{*} 13$ (citing Greater Balt. Ctr. for Pregnancy Concerns, Inc. v. Mayor of Balt., 721 F.3d 264, 285-86 (4th Cir. 2013)).

143 See Radiance Found. Inc., 2015 WL 2372675, at *13 (stating that the key to making the determination of commercial speech in that case was whether a reasonable person reading the trademark appropriator's article would think that the defendant was advertising a service or proposing a transaction).

144 See generally Lamparello v. Falwell, 420 F.3d 309, 312, 314 (4th Cir. 2005) (citing People for Ethical Treatment of Animals v. Doughney, 263 F.3d 359 (4th Cir. 2001)); Jews For Jesus v. Brodsky, 993 F. Supp. 282 (D.N.J. 1998), aff'd, 159 F.3d 1351 (3d Cir. 1998); Planned Parenthood Fed'n of Am., Inc. v. Bucci, No. 97 CIV. 0629 (KMW), 1997 WL 133313, at *1 (S.D.N.Y. Mar. 24, 1997), aff'd, 152 F.3d 920 (2d Cir. 1998).

14515 U.S.C. $\& 1125(c)(3)(C)$ (2012) (excluding noncommercial uses from dilution actions). 
only to defray the cost of the anti-smoking campaign. ${ }^{147}$ Therefore, under Riley, one could argue that the noncommercial nature of the speech predominates such that "expression should be evaluated under the test for fully protected expression." 148 Under the factors approach, this outcome appears to lead to the same result as the speech in a spoof ad; while not providing legitimate advertisements, Adbusters has a social, rather than economic motivation for the speech, and it would be difficult to claim that a person coming across a Joe Chemo image would think that a commercial transaction was being proposed.

But even in infringement cases, the noncommercial use of a trademark should be subject to strict scrutiny under the First Amendment, which would almost always be fatal to the injunctions issued. ${ }^{149}$ Nevertheless, courts in many instances only apply an intermediate level of scrutiny to these injunctions. ${ }^{150}$

\section{The Applicability of Strict Scrutiny to Trademark Injunction as Content-Based Regulations on Speech}

While there are a multitude of reasons why courts do not subject trademark injunctions to a First Amendment analysis, the main reason is because these injunctions are considered to be content-neutral speech regulations. This section will first demonstrate why trademark injunctions are in fact contentbased speech regulations before illustrating the differing level of scrutiny that results from the two classifications and the impact this has on the constitutionality of the injunctions issued.

Trademark Dilution Revision Act, supra note 131.

Ramsey, supra note 49, at 401 (citing Riley V. Nat'l Fed'n of the Blind of N.C., Inc., 487 U.S. 781, 796 (1988)).

See United States v. Playboy Entm't Group, Inc., 529 U.S. 803, 817 (2000) (citing R.A.V. v. St. Paul, 505 U.S. 377, 382 (1992)) (stating that content-based restrictions on speech which are subject to strict scrutiny are presumptively invalid); see also Ramsey, supra note 49, at 427-28 (asserting that when the Court applies strict scrutiny analysis it is almost always fatal to the regulation). 


\section{Trademark Injunctions as Content-Based Regulations on Speech}

The main reason courts do not apply strict scrutiny to trademark injunctions is due to the belief that trademark law is content neutral. 151 Since the injunction must reference the speech's content, however, such injunctions are in fact content-based speech restrictions, which should be subject to strict scrutiny.

To determine whether a regulation is content-based or content-neutral, courts look to the purpose of the regulation. ${ }^{152} \mathrm{~A}$ mere assertion that a regulation has a content-neutral purpose is insufficient to shield it from classification as content-based. ${ }^{153}$ Therefore, courts may also consider the substance of the regulation to glean evidence of the government's purpose. ${ }^{154}$

Whether or not a restriction on speech is content-based depends on whether the regulation merely regulates the medium - time, place or manner-in which the speech is dispersed and not the content of the speech itself. ${ }^{155}$ Under United States v. O'Brien ${ }^{156}$ and Ward $v$. Rock Against Racism, ${ }^{157}$ a regulation is content-neutral if it does not reference the speech's content and adequate

151 Ramsey, supra note 49, at 431-32 (citing S.F. Arts \& Athletics, Inc. v. U.S. Olympic Committee 483 U.S. 522, 536 (1987) (holding that the prohibition of certain uses of the word "Olympic" without authorization was constitutional as the law passed intermediate scrutiny and was contentneutral as the Act did not restrict the content of the message conveyed, but only the manner in which the sponsors could identify and promote their games)); Dall. Cowboys Cheerleaders, Inc. v. Pussycat Cinema, Ltd., 604 F.2d 200, 206 (2d Cir. 1979) (stating that the prohibition of the Lanham Act is content neutral); Dr. Seuss Enters., L.P. v. Penguin Books USA, Inc., 109 F.3d 1394, 1403 (9th Cir. 1997)) (stating that the prohibition of the Lanham Act is content neutral and does not arouse the fears that would trigger the application of constitutional prior restraint principles).

See Bartnicki v. Vopper, 532 U.S. 514, 526 (2001) ("In determining whether a regulation is content based or content neutral, we look to the purpose behind the regulation....").

Turner Broad. Sys., Inc. v. FCC, 512 U.S. 622, 642-43 (1994).

See Ramsey, supra note 49 , at 430 .

See id. at 427 .

391 U.S. 367,377 (1968).

491 U.S. 781, 791 (1989). 
alternative avenues of communication exist. Determining whether the use of a trademark is infringing requires looking at the content of the speech, unlike consideration of true content-neutral speech restrictions such as restrictions on sound amplification devices on trucks and laws regulating the noise levels at concerts. ${ }^{158}$ Furthermore, the argument that trademark laws are content-neutral because prohibiting the use of a word in registered trademark does not prohibit the speaker's ultimate message since adequate alternative avenues of communication exist is also problematic. The use, especially of famous marks, serves not only to identify the source of a product, but also identifies certain qualities and characteristics associated with that product.159 The prohibition of the use of such a mark therefore deprives the speaker of the ability to adequately convey his message to his audience by drawing an association between his message and the symbolic references of the mark. ${ }^{160}$

The application of $O^{\prime} B r i e n$ and Ward to our hypothetical litigation cases illustrates why trademark injunctions should be considered content-based restrictions. In this instance, the injunction would have to look to the content of the Adbusters image in order to make a determination of whether trademark infringement has occurred. It would also have to reference the content of the Adbusters image within the injunction itself as the injunction will explicitly prohibit the use of the Joe Chemo personality-a constitutive element of the Adbuster message. These explicit references to the content of the infringing users' speech are steps that must be taken in every trademark infringement case. This is why trademark regulations are unlike consideration of other content-neutral speech restrictions. ${ }^{161}$

Furthermore, the inability to use the Joe Chemo personality would reduce the efficacy of Adbusters' message. A poster stating "Smoking Kills" does convey the same message to the public, but lacks the force and interest created by the Joe Chemo character. Therefore, while alternative modes of communication do exist, they are not of equal value. The prohibition of famous

158 Ramsey, supra note 49 , at $435-36$.

159 Id. at 437.

160 See Radiance Found. Inc. v. NAACP, No. 14-1568, 2015 WL 2372675, at *14 (4th Cir. May 19, 2015) ("' $[I]$ t is often virtually impossible to refer to a particular product for purposes of comparison, criticism, point of reference or any other such purpose without using the mark."') (quoting New Kids on the Block v. News Am. Publ'g, Inc., 971 F.2d 302, 306 (9th Cir. 1992)).

Ramsey, supra note 49 , at $435-36$. 
marks deprives the speaker of the ability to adequately draw an association between his message and the symbolic references of the mark. Also, by requiring Adbusters to use different language to convey its message to the public, the court would be once again regulating the content of its message and not merely the medium - time, place, or manner-in which the message is conveyed.

Despite this seemingly apparent doctrine, the jurisprudence distinguishing content-based from content-neutral regulations is complicated and inconsistent. Nonetheless, when analyzing speech regulations, the determination of content neutrality is critical because the level of scrutiny applied to the regulation determines whether or not the regulation is valid.

\section{Consequences of Applying Strict Scrutiny to Trademark Injunctions}

The application of an intermediate level of scrutiny to trademark injunctions would result in trademark injunctions withstanding a constitutional challenge, however, as demonstrated above, if the more appropriate strict scrutiny standard were used, most trademark injunctions would fail constitutional review.

Content-based regulations are viewed with extreme suspicion due to their potential to restrict expression because of its message, ideas, or subject matter. ${ }^{162}$ For a content-based restriction to survive strict scrutiny, it must be narrowly tailored and the least restrictive means of promoting a compelling government interest. ${ }^{163}$ As previously mentioned, the application of this level of scrutiny to a speech regulation is almost always fatal. ${ }^{164}$ Content-neutral regulations are subject to intermediate scrutiny as applied by $O^{\prime}$ Brien and Ward. Under this test, the regulation is legitimate if it furthers an important or substantial government interest that is unrelated to the suppression of free expression, does not reference the speech's content, and the restriction is no greater than necessary to further the legitimate government interest by leaving open ample alternative channels of communication. ${ }^{165}$

See Turner Broad. Sys. v. FCC, 512 U.S. 622, 641-42 (1994).

United States v. Playboy Entm't Grp., Inc., 529 U.S. 803, 813 (2000).

See supra Part II.

Ward v. Rock Against Racism, 491 U.S. 781, 791 (1989) (quoting Clark v. Community for Creative Non-Violence, 468 U.S. 288, 293 (1984)); United States v. O'Brien, 391 U.S. 367, 377 (1968). 
The application of these two different levels of scrutiny produces very different results when applied to an injunction against the noncommercial use of a trademark. Consider the divergent outcomes if these different standards of scrutiny were applied to the Adbusters' hypothetical.

If a court passed down an injunction requiring Adbusters to cease use of the Joe Chemo mark, the injunction could survive intermediate scrutiny as the important government interest would be the protection of R.J. Reynolds' rights in its trademark and the protection of R.J. Reynolds from being associated with an anti-smoking campaign that it does not endorse. Also, the content of Adbusters' message would not be hampered as there are a myriad of other methods that Adbusters could use to communicate its anti-smoking message to the public without making use of the tobacco company's trademarks.

The injunction, however, would most likely fail under a strict scrutiny analysis as it is uncertain whether courts would find that there is a substantial government interest in preventing consumer confusion regarding the sponsorship of the use of a mark in order to provide social commentary. ${ }^{166}$ Furthermore, as strict scrutiny requires that the least restrictive means be used, the presence of a disclaimer on Adbusters' images stating that the tobacco company is not affiliated with Camel would be far less restrictive than the outright banning of the use of the mark.

\section{The Necessity of Finding a Way to Subject Trademark Injunctions to Constitutional Scrutiny}

While there is some validity to not subjecting trademark injunctions to a First Amendment analysis, the creation of a corpus of jurisprudence applying such a test or a safe harbor would lessen the opportunity for commercial trademark owners to bypass constitutional scrutiny when seeking to enjoin others from making noncommercial use of their marks.

Many reasons exist as to why courts would hesitate to apply a First Amendment analysis to trademark laws and injunctions. One of these might be because courts consider that trademark law contains built-in First Amendment protections and does not need an additional layer of judicial oversight. 167 The

See Ramsey, supra note 49, at 445.

167 See id. at 446 (suggesting that the Court may be governed by the logic used in Eldred v. Ashcroft, 537 U.S. 186, 218-19 (2003), a copyright case where the 
issue of judicial efficiency must also be addressed. Currently, courts must interpret the Lanham Act narrowly when the infringing use is part of an expressive work. ${ }^{168}$ This requires a case-by-case contextual analysis that allows the court to adjudicate trademark infringement cases with flexibility. It has the substantial disadvantage, however, of lacking predictability. Therefore, individuals and small firms who are defendants in an infringement suit will be unable to predict the outcome of their case and will likely settle and agree to stop using the trademark, resulting in a de facto chilling of speech. ${ }^{169}$

Issues of judicial efficiency would also exist if courts were to automatically apply a First Amendment analysis to every injunction ordered in a trademark infringement case. ${ }^{170}$ The inclusion of First Amendment reasoning would allow for the creation of a body of jurisprudence that could be applied in subsequent cases, reducing the need for every court to carry out an individual First Amendment analysis. ${ }^{171}$ Another solution that could resolve the conflict between the First Amendment and trademark doctrines is the adoption of safe harbors, either to remove certain acts from being classified as infringement or to protect certain actors, such as internet service providers, from liability in infringement cases. ${ }^{172}$ The adoption of safe harbor rules would provide a degree of predictability to trademark fair use and make it easier to dispose of meritless cases, but would lack the flexibility of a case-by-case approach. While any of these methods would resolve the current conflict, courts should not be allowed to continue to bypass the issue by incorrectly characterizing trademark law as content-neutral rather than content-based restrictions on speech.

\section{RECONCILING SPEECH AND TRADEMARKS}

While the wholesale application of First Amendment doctrine to trademark law is undesirable, courts should adopt mechanisms from other areas of law to resolve the outstanding conflict between First Amendment and trademark doctrines.

Court refused to impose "uncommonly strict scrutiny on a copyright scheme that incorporates its own speech-protective purposes and safeguards").

Tommy Hilfiger Licensing, Inc. v. Nature Labs, 221 F. Supp. 2d 410, 414 (S.D.N.Y. 2002).

See Ramsey, supra note 49 , at 449.

See id. at 452.

Id.

Id. at 456 . 
The current state of trademark law encroaches on the First Amendment first by employing a different standard for "misleading and deceptive" speech and then by allowing injunctions against the noncommercial use of trademarks to bypass First Amendment strict scrutiny. The current system also encroaches on the First Amendment in another way. Trademark litigation is very costly and unpredictable. Therefore, most noncommercial users acquiesce upon receipt of a cease and desist letter. ${ }^{173}$ Added to this is the risk that trial courts sometimes incorrectly apply trademark law, especially when navigating murky areas such as the commerciality of speech. Activist defendants must then have the economic wherewithal to sustain an appeal rather than succumb to an injunction issued at the trial court level. ${ }^{174}$ This judicial landscape has the effect of chilling speech protected by the First Amendment. ${ }^{175}$

The full-fledged application of First Amendment doctrine to trademark law, however, is undesirable, as it would require a fact-intensive investigation for each infringement case to determine if there should be liability. ${ }^{176}$ The burden of showing actual confusion to prove misleading speech and removing First Amendment protections from the defendant would be too great for most plaintiffs to bear. If required to do so, businesses would face increased costs due to the high degree of unpredictability in trademark litigation. The resulting decrease in trademark infringement cases would be undesirable-the interest of trademark law to protect consumers from confusion is a laudatory one that should be promoted. A solution to this problem might be to establish per se tests under which certain statements would be recognized as per se infringement and therefore require no further proof. ${ }^{177}$ This is the approach used in defamation law. ${ }^{178}$ Another solution may be an explicit exclusion of the commercial use of trademarks from constitutional scrutiny in the interest of protecting consumers.

See id. at 405 .

See e.g., Radiance Found. Inc. v. NAACP, No. 14-1568, 2015 WL 2372675 at *2 (4th Cir. May 19, 2015) (reversing the district court's finding that defendants had used the trademark in connection with goods and services in a manner likely to create a likelihood of confusion).

Ramsey, supra note 49, at 404-05.

Tushnet, supra note 66, at 752 (citing Judge Richard Posner's determination that trademark infringement is a case-specific question of fact, then rejecting the analysis in certain situations where speech is inherently false).

See id. at 752-53.

Id. at 752 . 
This is the approach the Court takes under speech regulations in antitrust, securities, labor, and evidence law, among others. ${ }^{179}$ In these cases the Court has found that strict scrutiny is unwarranted with little comment. ${ }^{180}$ Openly recognizing that trademark law occupies a unique place in First Amendment jurisprudence and structuring a framework to protect the freedom of expression of trademark appropriators could temper trademark law's chilling effect on speech. ${ }^{181}$

\section{CONCLUSION}

Tobacco products and the speech surrounding the marketing of these products are heavily regulated in the United States, notably under the Family Smoking Prevention and Tobacco Control Act. ${ }^{182}$ These regulations have been routinely subject to well-funded constitutional challenges by the tobacco industry. The statutes currently in place, however, have survived First Amendment scrutiny as courts have determined that tobacco companies' speech rights have only been curtailed to the extent necessary to advance the government's stated interest in passing each legislation. Were the United States to enact a Plain Packaging Act similar to Australia's law, the tobacco industry would no doubt argue that the curtailment of its speech was more than necessary to advance public health objectives. explained why-for various political, economic, social, and cultural reasons-certain areas of the law are placed outside the boundaries of the First Amendment).

181 Id. at $384-85$ (claiming that under the current regime, protected expression is frequently chilled because the First Amendment safeguards built into trademark law are too limited and too costly a burden for most defendants to bear).

182 Family Smoking Prevention and Tobacco Control Act, Pub. L. No. 111-31, 123 Stat. 1776 (2009) (codified in scattered sections of 5, 15, and 21 U.S.C.); see e.g., Master Settlement Agreement (Nov. 1998), available at http://publichealthlawcenter.org/sites/default/files/resources/mastersettlement-agreement.pdf (limiting the advertising, marketing and promotion of cigarettes by prohibiting advertising on outdoor, billboard and public transit adverting and the use of tobacco trademarks on other products and prohibiting the advertisement of tobacco products to people under the age of 18). 
Trademark disputes are another set of issues in which tobacco companies flex their muscles in court. In these contexts, tobacco companies often seek to enjoin the speech of others, be they competitors who use similar fonts or packaging designs, or parodists who ridicule their marks. Tobacco companies vigorously protect their marks because their brands are valuable. The enormous value attached to tobacco brands, however, is in decline as governments and public health campaigns attack the companies' marketing strategies.

The rigorous First Amendment scrutiny that is so prevalent in tobacco regulation disputes is simply non-existent in trademark disputes. The juxtaposition of treatment received in actions aimed at the marketing of tobacco products in these bodies of law reveals different legal standards in two areas of law that are otherwise parallel. Different standards exist for the requisite level of deception, evaluation of content neutrality, and the determination of what is noncommercial. While tobacco regulation cases have further developed First Amendment doctrines, the application of those doctrines to trademark law remains unclear. The result is that speech rights in the trademark context are in a state of disarray. As regulations tighten on the appearance of marks relating to tobacco products, the Court may reconsider the arguments adopted in tobacco trademark litigation and provide greater clarity regarding the First Amendment implications of trademark law. 